\title{
La Numancia de Rafael Alberti en la guerra civil española
}

Recibido: 15/12/2019. Aceptado: 14/6/2020.

\begin{abstract}
Resumen
El 18 de julio de 1936 se produce el levantamiento militar que desencadena la querra civil española, enfrentando a los bandos nacionalista y republicano. En este contexto emerge el denominado teatro de urgencia, cuya finalidad era funcionar como un instrumento de agitación y propaganda al servicio de la causa republicana. Se planteaba combinar la temática revolucionaria coetánea con los clásicos del teatro del Siglo de Oro, porque poseían una conexión con las masas populares que los dramaturgos contemporáneos no podían ignorar. En 1937, Rafael Alberti se apropia de la Numancia cervantina, adaptándola y poniéndola al servicio de la causa republicana, por su ejemplo heroico, cuando comienza la ofensiva nacionalista sobre Madrid y es imperioso alentar a los combatientes y a la población civil en la resistencia. El texto albertiano está hecho en vistas de la lucha y resistencia republicana y no se vislumbra una posible derrota, pues los españoles se convertirán en los vengadores de Numancia. El presente trabajo aborda la Numancia de 1937, su proceso de reescritura a través del paradigma de la hipertextualidad de Gerard Genette, la resignificación del texto cervantino en el contexto bélico español, y cómo esta versión funciona como un parapeto ideológico para exaltar los valores republicanos.
\end{abstract}

\section{The Numancia of Rafael Alberti in the Spanish Civil War}

\begin{abstract}
On July $18^{\text {th }} 1936$ a military uprising occurs which triggers the Spanish Civil War confronting two sides: nationalists and republicans. In this context the so-called emergency theatre arises with the purpose of functioning as an instrument of agitation and propaganda at the service of the republican cause. The aim of this theatre is to combine the revolutionary theme of the time with the classics of the Golden Age theater, since they had a connection with the popular masses that contemporary playwrights could not ignore. In 1937 Rafael Alberti appropriates Cervantes's Numancia adapting
\end{abstract}

Palabras clave Cervantes Alberti Numancia teatro reescritura

Keywords Cervantes Alberti Numancia theater rewriting 
it and putting it at the service of the republican cause to highlight its heroic example when the nationalists start to attack Madrid and it is essential to encourage fighters as well as civilians in the resistance. Alberti's work stands out the republicans' fight and resistance leaving no place for a possible defeat and will become Spanish people as Numancia avengers. The present work relates to Numancia in 1937, its rewriting process through the paradigm of Gerard Genette's hypertextuality, the resignification of Cervantes's text in the Spanish war context, and how this version functions as an ideological parapet to exalt the republican values.

\section{La Numancia de Cervantes: historia y leyenda}

Entre 1580 y 1587, Miguel de Cervantes compuso El cerco de Numancia, una tragedia en verso que narra la destrucción de la ciudad celtíbera a manos del general Escipión en el año 133 a.C. Luego de soportar varios años de asedio, los numantinos optan por la muerte colectiva antes que caer bajo el yugo romano.

La historia, inspirada en hechos reales, puede rastrearse en diversas fuentes antiguas, como Guerra numantina de Lucio Floro e Ibéricas de Apiano Alejandrino. Ambos cronistas coinciden en que el cerco duró catorce años y que varios generales romanos desistieron del asedio ante su fracaso (Albistur, 1968). Fue entonces cuando se designó a Escipión, el más poderoso militar romano, para dirigir el sitio, y es a partir de este momento de la historia numantina que Cervantes escribe su tragedia. Luego de una prolongada resistencia ante el invasor, y a pesar de los actos valerosos en su defensa, los numantinos, rendidos por la hambruna, deciden acabar con sus vidas antes que entregarse a los romanos. Cuando Escipión finalmente ingresa en la ciudad, solo encuentra silencio, desolación y muerte.

Respecto al desenlace, hubo dos versiones. Según Apiano, los numantinos entregaron la ciudad y, si bien muchos optaron por una muerte honrosa, hubo prisioneros que acompañaron a Escipión en su regreso victorioso a Roma. Según Lucio Floro, ningún numantino permaneció con vida (Cortadella, 2009), y esta segunda versión es la adoptada por el imaginario colectivo español durante el siglo XVI (Vivar, 2000).

El sentimiento de nacimiento y patria, así como el ideal de la muerte por esta última, estuvieron relacionados durante siglos con el concepto de nación para transmitir la unión del hombre con la tierra donde nació y plasmar la diferencia con el extranjero. El tópico pro patria mori y el concepto de natio, heredados de la antigüedad romana, resurgen con fuerza durante el período humanista por medio del mártir cristiano y de un nuevo sentimiento patriótico (Vivar, 2000). ${ }^{1}$ Desde la antigüedad, los pequeños pueblos construyen su identidad en la lucha por la libertad, tópico que adoptan las naciones europeas para construir sus héroes semi-míticos basándose en los caudillos que lucharon por la libertad de su pueblo contra Roma. En el caso español, los historiadores construyen una imagen histórica popular y nacional en la figura de Viriato, una representación del primitivo nacionalismo hispánico, que servirá de instrumento de propaganda para la construcción de un sentimiento de patriotismo (Vivar, 2000). Según Vivar (2000), este sentimiento es un fenómeno generalizado en el siglo XVI, impulsado por los humanistas a través de diversas áreas de estudio como la defensa de las lenguas vernáculas o la escritura de historias nacionales. En España, los estudios historiográficos de Florián de Ocampo y su continuador Ambrosio de Morales dotaron a la monarquía hispánica de un pasado glorioso, y estos esfuerzos son acompañados por un intento de creación de un teatro nacional inspirado en crónicas y leyendas épicas autóctonas (Cortadella, 2009). 
El sentimiento patriótico está íntimamente relacionado con el Imperio, su fervor garantiza la unión, y El cerco de Numancia se ubica en este contexto ideológico. Albistur (1968) afirma que la obra cervantina es una gesta española por donde se la observe, porque "Numancia se levantó junto al Duero y este elemento llena de entusiasmo patriótico al escritor" (Albistur, 1968: 36).

Por su parte, Jordi Cortadella (2009) afirma que Cervantes contribuyó a alentar el espíritu revanchista español, un ejercicio de propaganda de la corona y de la guerra justa, consecuente con la sociedad española del siglo XVI, combativa en varios frentes bélicos. Porque el Imperio español, en contraposición al romano, es poseedor de consideraciones morales, éticas y religiosas: España no es una sitiadora de otros pueblos, sino un Imperio del Bien, cuya misión histórica, política y moral es luchar contra el mal del mundo (Cortadella, 2009).

Durante los reinados de Carlos V y Felipe II se construye un fuerte referente histórico para la identidad colectiva. El pasado se utiliza para explicar y justificar el devenir español en una sociedad obsesionada por los orígenes y la legitimidad del poder (peninsular e internacional), por lo tanto, resulta imperioso explicar cómo una potencia mundial había sido sometida en la antigüedad. Cortadella (2009) señala que la razón de este relato de la historia y de esta construcción del pasado se encuentra en el pecado de la desunión de los primitivos españoles, es decir, los numantinos: el dominio extranjero - el romano- fue la penitencia y luego vino la redención, que se inicia con los visigodos y continúa con la monarquía de los Austrias, en donde un pueblo purificado por la penitencia inicia el ascenso hacia la hegemonía.

En la obra de Cervantes, las alegorías del Duero y la Fama expresan el determinismo de la Providencia: la obstinación de un pequeño pueblo hispano, que desafía el poder romano, se convierte bajo las profecías del Duero y la Fama en vaticinio de la gloriosa historia de España. El presente es un heredero del pasado, pues las virtudes numantinas sobreviven en las siguientes generaciones de españoles, y la España del siglo XVI es una orgullosa heredera de los numantinos y godos, y Cervantes contribuye con su obra a fomentar este orgullo patrio.

\section{La Numancia de 1937: contexto político-cultural}

El 18 de julio de 1936 se produce el levantamiento militar que desencadena la guerra civil española, enfrentando a los bandos nacionalista y republicano. La Alianza de Intelectuales Antifascistas, las Guerrillas del Teatro y el Teatro de Arte y Propaganda de Madrid fueron vehículos de propaganda a través de los cuales los intelectuales comprometidos con la causa republicana pusieron su actividad creadora a su servicio (Hermenegildo, 1979). La guerra originó un nuevo tipo de teatro, denominado teatro de urgencia - debido a las circunstancias políticas-, que formaba parte de una renovación teatral en la década de los treinta, y tenía por objetivo mostrar la antigüedad de la revolución, la larga lucha del pueblo español, y expandir la resistencia ante la sublevación fascista (Jiménez León, 2000). El Teatro de Arte y Propaganda -órgano del partido comunista destinado a usar el teatro con fines propagandísticos- planteó el retorno a los textos clásicos combinados con la temática revolucionaria coetánea, debido a que el teatro del Siglo de Oro poseía una capacidad de conexión con las masas populares que los dramaturgos contemporáneos no podían ignorar (Baras Escolá, 2014). Rafael Alberti se encargó de adaptar diversos clásicos en función de la causa política, y en la tarea de restituirle la Numancia al pueblo español se inscribe su versión, porque la obra constituía un teatro de propaganda y al mismo tiempo un teatro de arte. En 1937, Alberti se apropia de la tragedia cervantina, adaptándola y poniéndola al servicio de la causa republicana, por su ejemplo heroico, cuando comienza la 
2. Pardo García (2010) realiza una distinción entre escritura "homodiegética" o "literal” (no transforma el universo diegético original, sino que lo expande o complementa) y escritura "heterodiegética" o "desplazada" (transforma el universo diegético, cuya forma más expandida es la "aproximación", pero sin olvidarse de la transmotivación y la transvaloración).

3. La transformación o transposición supone introducir modificaciones de índole formal y/o temática en un texto. La modificación formal abarca: la forma externa, el estilo, la extensión y el modo (Genette, 1989).

4. Todas las citas de la Numancia de Miguel de Cervantes corresponden a la edición de Madroñal Durán (2014). ofensiva nacionalista sobre Madrid y era imperioso alentar a los combatientes y a la población civil en la resistencia. Al respecto afirmó: "Nosotros que ahora luchamos contra Roma, contra la Italia fascista, debemos conocer y apreciar en todo su valor, y a través de la gran tragedia cervantina, la historia de Numancia" (Jiménez León, 2000: 1180), estableciendo, así, un paralelismo entre la histórica defensa de Numancia y la heroica defensa de Madrid por los republicanos. La versión numantina de 1937 está hecha en vistas de la lucha y resistencia republicana, y no se vislumbra una posible derrota, porque los españoles se convertirán en los vengadores de Numancia.

\section{La reescritura de la Numancia de Rafael Alberti}

La Numancia de Rafael Alberti es un hipertexto - según Genette (1989), la hipertextualidad es el término que denomina la relación macrotextual que se establece entre una fuente (hipotexto) y la imitación o transformación que de ella realiza un texto posterior (hipertexto)-, que presenta una reescritura heterodiegética o desplazada, ${ }^{2}$ porque cambia el universo diegético creado por Miguel de Cervantes y opera una transformación dominada por la aproximación, ya que realiza un movimiento de traslación a las coordenadas geográficas, temporales, sociales y nacionales del texto resultante. La historia de Numancia ya no transcurre en la ciudad celtíbera en el siglo III a.C., asediada por el ejército romano al mando de Escipión, sino en la ciudad de Madrid, en el año 1937, cercada y bombardeada por el ejército franquista y sus aliados, en el marco de la guerra civil española, y defendida por el ejército republicano y la milicia. Esta versión de la tragedia cervantina supone una transposición, porque trata de contar la misma historia, pero de una forma nueva, introduciendo una serie de transformaciones a nivel formal y temático, que repercutirán en el plano semántico.

\subsection{Modificación formal}

En un primer nivel, el formal, ${ }^{3}$ el hipertexto presenta cambios en la extensión (translongación) (Genette, 1989). La tragedia cervantina, dividida en cuatro jornadas con un total de 2448 versos, se convierte en la versión de Alberti en una obra repartida en tres jornadas constituida por 1587 versos, como resultado de supresiones y transformaciones que abarcan escenas, diálogos y personajes. Son eliminados o transformados 107 versos en la Jornada Primera, 334 en la Jornada Segunda y 157 en la Jornada Tercera. Los versos añadidos son 35 en el prólogo, 59 en la Jornada Primera, 16 en la Jornada Segunda y 66 en la Jornada Tercera. Se suman 41 acotaciones renovadas y 17 nuevas, muchas de estas con presencia de la música, y el autor solo conserva una acotación sin cambios (Baras Escolá, 2014).

Uno de los pasajes más importantes del texto cervantino - las escenas referentes al sacrificio y el cuerpo amortajado (necromancia observada por Marandro y Leoncio) y la conjuración de Marquino- desaparece en Alberti. Se pierde un total de 327 versos, lo que provoca la reorganización del texto en tres actos, quedando unidas partes de la segunda jornada con la tercera. Esta supresión produce una alteración del sentido inicial de la obra, porque en la predicción de la muerte inicial de Numancia Cervantes incluye el triunfo de la pervivencia de la fama numantina en los futuros logros españoles. El sacerdote $2^{\circ}$ afirma: "Si acaso, yo no soy mal adivino / nunca con bien saldremos desta empresa. / ¡Ay, desdichado pueblo numantino!" (vv. 791793). ${ }^{4}$ El muerto resucitado por Marquino también expresa malos augurios: "a que acabe, Marquino, de informarte / del lamentable fin, del mal nefando / que de Numancia puedo asegurarte" (vv. 1067-1069). Cervantes ubica la visión mágica en un convencional tiempo futuro observado desde su propio presente. De esta manera, el emisor y el receptor aceptan el código en que se transmite el mensaje, ya que su 
experiencia les posibilita comprobar la ejecución de las profecías, que cantan las futuras glorias españolas basadas en el suceso heroico de Numancia. Para Alberti, estas profecías no justifican la predicción del trágico final de la ciudad, razón por la que suprime la escena del conjuro, porque su conservación hubiera agregado connotaciones opuestas a los intereses del mensaje del autor. La anulación de este pasaje cargado de magia, religión y simbología es acompañada por la eliminación de la mayoría de las alusiones históricas referentes a la mitología grecolatina: Júpiter, Plutón, Venus, Ceres, las tres parcas, la fortuna, los agüeros, los augurios y las estrellas. Solo conserva mínimamente los hados y los cielos, dato significativo, porque en el texto de Cervantes el destino ocupa un lugar relevante. Las referencias a un destino preestablecido parecen quitarle relevancia a la decisión final del pueblo numantino:

\author{
Empero agora, que ha querido el hado \\ reducir nuestra nave a tan buen puerto, \\ las velas de la guerra recogemos \\ y a cualquier partido nos ponemos (vv. 252-255)
}

En la adaptación de Alberti estas supresiones pueden obedecer a diversas razones: la lejanía que supone la temática mitológica para el espectador actual, la distracción en la atención sobre el profundo caso humano que se planteaba, la agilización del texto eliminando todo aquello que un público poco cultivado -integrado mayoritariamente por milicianos - no pudiera comprender, o la incompatibilidad con el espíritu librepensador y enemigo de supersticiones de un republicano y comunista como era el autor.

Respecto a las alusiones históricas, Alberti ha evitado la incidencia histórica cervantina en varios pasajes sustituyéndola por la contemporánea. Sucede, por ejemplo, con el discurso de los embajadores numantinos, cuando expresan el pensar de Numancia ante Escipión sobre la sumisión a Roma:

Dice que nunca de la ley y fueros

del romano senado se apartara

si el insufrible mando y desafueros

de un cónsul y otro no le fatigara (vv. 241-244)

Se trata de un pasaje que no se justifica emocionalmente, porque es incompatible con el mensaje libertario que intenta transmitir Alberti, pero también anularía la ambigüedad del referente Numancia / Madrid, ya que la sumisión a Roma no es una condición existente en el referente Madrid. Otro ejemplo es el discurso del río Duero, al finalizar la Jornada Primera, donde el autor suprime los elementos históricos que anuncia el Duero al tratar del futuro de España: profetiza el sometimiento de los romanos por Atila, la llegada de los godos, del duque de Alba, el advenimiento al trono de Felipe II, la unificación de Portugal y España, entre otros sucesos. En su lugar, en la versión de Alberti, el río Duero visualiza el futuro hecho realidad en la guerra civil española realizando una referencia explícita al presente, a hechos de la contienda bélica. Los versos potencian la identificación entre los romanos y los italianos, y aluden a la batalla de Guadalajara, donde las tropas republicanas vencieron a los fascistas italianos:

Adivino, querida España, el día en que, pasados muchos siglos, lleguen

cómplices del terror y la agonía, los malos españoles que te entreguen a otro romano de ambición sombría. 
5. La Numancia de Rafael Alberti se cita siempre por la edición de 1937, cuyos versos no están numerados, se indicará en el texto la página correspondiente.
Pero su sepultura más preclara

se la reservará Guadalajara $(40-41)^{5}$

En otro pasaje, el río Duero proclama:

A tus obreros, madre y campesinos de soldados verás por los caminos. Verás también los jefes populares surgir de tus rincones (41)

Estos versos poseen una simbología explícita que refiere al comunismo, representado en las clases populares que llevaron a cabo la revolución socialista. El final de la Jornada Segunda, al igual que el de la Primera, también cierra con alusiones al enfrentamiento bélico. El trágico final en Cervantes, donde madre e hijo se encaminan hacia la hoguera donde morirán, es sustituido en Alberti por un desenlace esperanzador: "Los hijos de esa roja hoguera / darán a España lo que espera" (41).

Se puede decir que las alusiones históricas, las referencias a la mitología grecolatina y el pasaje vinculado con el mundo de ultratumba son tres elementos importantes en el texto cervantino, porque encuadran, justifican y señalan la presencia del referente y la percepción del mensaje por el receptor. En palabras de Hermenegildo (1979), "se trata de una serie de señaladores, íconos o símbolos con los que el autor ha codificado el mensaje que está intentando transmitir al espectador" (Hermenegildo, 1979: 157). Pero, cuando el receptor / espectador varía, esta serie también lo hace, por lo menos en sus dimensiones más condicionadas por la contingencia espacio-temporal, fenómeno que sucede en la adaptación albertiana.

Otra variante que realiza el escritor refiere a las extensas tiradas de versos pronunciadas por ciertos personajes. Los largos parlamentos que expresan las madres I y II en Cervantes son repartidos entre cuatro de ellas y se eliminan algunos versos resultando parlamentos de menor extensión. Lo mismo sucede con el río Duero, sus palabras son repartidas entre él y sus afluentes Orvión, Minuesa y Tera, recurso que también se aplica en algunos numantinos y en el largo parlamento del Hambre, que queda fraccionado entre la Guerra y la Enfermedad, y se eliminan algunos personajes secundarios como Gayo Mario, Marquino, Milbio, Ermilio, Limpio y otros.

Alberti agrega una escena en su versión que corresponde al inicio en forma de prólogo y antecede a la tragedia, contrastando con el comienzo abrupto de Escipión en Cervantes:
Esta difícil y pesada carga
que el Senado romano me ha encargado, tanto me aprieta, me fatiga y carga
que ya sale de quicio mi cuidado" (vv. 1-4)

Interpretada por Macus y Buco, dos personajes del teatro cómico latino, su humor aligera y hace más comprensible la llegada y arenga de Escipión al campamento romano. Maccus y Bucco junto a Pappus y Dossennus eran dos de los personajes arquetípicos de la farsa atelana, pieza teatral breve de tono humorístico, propia del teatro latino primitivo, que se remonta al siglo IV a.C., cuyo tema principal era la farsa y en ocasiones se atacaba o ridiculizaba a los poderosos. La farsa atelana se caracterizaba por la presencia de personajes tradicionales enmascarados, que recibían dichos nombres y representaban arquetipos: el anciano, el charlatán, el bufón y el necio. A través del diálogo desopilante entre Macus y Buco, Alberti plasma la corrupción del ejército romano, evidenciando una carga emotiva agresiva, producto de la cercanía 
espacio-temporal que media entre el referente y el emisor. El juego de palabras con connotación sexual manifiesta el carácter prostibulario del ejército enemigo de la República:

Buco: ¿Me dices lo que tienes?

Macus: ¡Ay, mejor, ay, será que no lo diga!

Buco: ¿Penas?

Macus: ¡Ay! ¡Ay!

Buco: ¿Por culpa de que [sic] penes? (21)

Más adelante continúan las expresiones con doble sentido, que evidencian el degeneramiento de los romanos. Macus, disfrazado de mujer embarazada, expresa lo siguiente:

\author{
Quien no quiera guerrear \\ que se vista de mujer \\ y busque al anochecer \\ una aguja que enhebrar. \\ ¿Quien [sic] me la quiere enhebrar? (25)
}

La escena finaliza con bailes y canciones eróticas, ${ }^{6}$ que reflejan la flojedad reprochada por Escipión a sus tropas, explicitando el mensaje de agresión de parte del autor hacia el ejército romano.

Dentro de las transformaciones formales, el texto albertiano también presenta modificaciones en la forma externa referente a la versificación. La forma métrica utilizada por Cervantes - octavas reales - es sustituida, en algunos casos, por quintetos y sextetos intercalados en estrofas completas y algunos tercetos encadenados quedan resueltos en formas métricas desconocidas para quitarle monotonía a los versos cervantinos (Baras Escolá, 2014). En la escena donde la figura simbólica de España pide ayuda al río Duero y este pronostica el sometimiento de los romanos, el saqueo de Roma y el trono de Felipe II, Alberti sustituye las octavas reales cervantinas por una propia, alusiva a los tiempos presentes españoles. Junto a ello se observa una transestilización (transformación en el estilo), pues el autor no intenta imitar el estilo de escritura de su predecesor; por el contrario, moderniza el léxico y agiliza el ritmo presentando un carácter más directo y coloquial que su hipotexto ligado al modo (transmodalización intramodal), ${ }^{7}$ porque el texto albertiano presenta cambios narrativos de tiempo, distancia y focalización en la representación, para actualizar el pasado y acelerar el ritmo de la obra cervantina.

\subsection{Modificación temática}

En la Numancia de 1937 suceden cambios diegéticos referentes al valor que se atribuye a una acción y al personaje que la protagoniza, mejorándolo o degradándolo, correspondiendo a un tipo de transformación que Genette (1989) denomina transvaloración. ${ }^{8}$

En El cerco de Numancia la figura del general Cipión es enaltecida a través de ciertos adjetivos calificativos. Cuando Cervantes llama al general "buen señor" (v. 224), en boca del Numantino I, o "ínclito general" (v. 234), o se hace referencia a "tu real grandeza" (v. 231), la versión de Alberti se limita a tratarle únicamente de "señor" (32). En algunos pasajes cervantinos donde se explicita el sometimiento al general romano se modifica el signo, porque resulta inadmisible, para un receptor comprometido con su propia libertad, tal concesión frente al enemigo de la causa republicana. Mientras en Cervantes los embajadores de Numancia le dicen a Cipión "si por señor y amigo te tenemos" (v. 263), en Alberti los personajes expresan "si al final por amigo te tenemos" (33). Situación parecida sucede con la respuesta de estos embajadores en otro
6. M. Mar Puchau de Leccea (2014) destaca la raíz popular y la tradición hispánica como elementos presentes en las obras de Alberti, y entiende que el prólogo que le agrega a la tragedia cervantina, protagonizado por dos personajes cómicos del teatro latino, da cuenta de esto. La escena cargada de juegos escatológicos, doble sentido en el lenguaje, risas, bailes y borracheras expresa la carga burlona y satírica, de origen hispánico, y el tono popular que lo aproxima a todas las clases sociales y culturales.

7. Según Genette (1989), la transmodalización puede ser “intermodal” (dramatización y narrativización) e "intramodal” (cambios narrativos de tiempo, distancia, focalización, entre otros).

8. Genette (1989) divide la modificación temática entre tres subtipos: diegética, pragmática y semántica. La modificación diegética más común es la denominada “aproximación”: el desplazamiento a las coordenadas espacio-temporales del hipertexto. Pero también contempla cambios en el sexo o en la edad de los protagonistas, en la valoración personal (transvaloración), entre otros (Genette, 1989). 
pasaje. En Cervantes se dice "de aquel que, siéndote enemigo / quiere serte vasallo y fiel amigo" (vv. 287-288), en la adaptación albertiana se modifica tal parlamento, de manera que la noción de vasallaje desaparece: "de aquel que, siéndote enemigo / quiere tenerte solo por amigo" (34). Otro tanto sucede con el valor que se atribuye al ejército romano. En la Jornada Segunda, cuando Corabino se refiere al ejército enemigo como "bravo ejército romano" (v. 562), en Alberti el adjetivo "bravo" se sustituye por la expresión "los fuertes ejércitos romanos" (49), eliminando, de esta manera, cualquier sentimiento de admiración hacia el contrincante.

En el texto cervantino se presenta a Cipión como un general preocupado por limpiar el campamento romano de todo aquello que va en contra de la pureza de la vida militar. Dice al respecto:

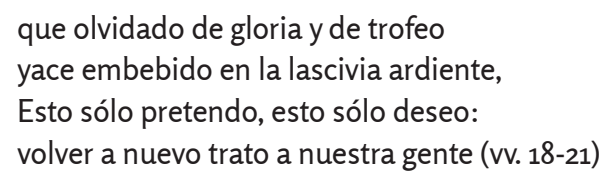

En su discurso a la soldadesca enumera los objetos que deben desaparecer de las tiendas: vino, juego y prostitutas. En Alberti no se manifiesta esta intención positiva, sino que se busca denigrarlos, y así los elementos relativamente descriptivos de Cervantes se convierten en su adaptación en signos icónicos de connotación negativa. El receptor puede percibir la corrupción del ejército romano desde el inicio de la obra, en el prólogo, donde se explicita el deseo de exponerlo y ridiculizarlo: "Se ven esparcidos por el campamento soldados borrachos, prostitutas, músicos, gentes que denotan una vida perezosa, libertina, olvidada de la querra" (20). En el final de la Jornada Tercera queda nuevamente plasmada la visión negativa sobre el adversario, cuando Viriato -el último numantino con vida - se arroja desde una torre. Los soldados romanos colocan su cuerpo sobre un escudo y Escipión pronuncia unas palabras junto con la Fama. La acotación dice al respecto: "Los romanos, dejando en tierra el escudo donde reposa el cuerpo de Viriato, atónitos, avergonzados, se cubren el rostro, mientras habla España dirigiéndose a ellos y a la Fama" (75). Se trata de una acotación, que tiene por finalidad destacar la crueldad de la acción realizada por los romanos, que induce al joven al suicidio, pero el efecto patético aumenta cuando los responsables se concientizan de la magnitud de su falta y dan muestra de ello.

La Numancia de Alberti también contiene transformaciones de tipo diegéticas referentes al universo espacio-temporal. Como se señaló en el comienzo, el hipertexto traslada la historia original al siglo XX, al año 1937, a la ciudad de Madrid, en el contexto de la guerra civil española. Aquí se distinguen la actualización (tiempo) y la indigenización (espacio) -término acuñado por Linda Hutcheon (Pardo García, 2010)- porque el cambio temporal es claro: en la obra de Cervantes la acción transcurre en el año 133 a.C., mientras en la de Alberti sucede en el año 1937 d.C., y si bien la acción se desarrolla en el mismo espacio - península ibérica-, transcurre en diferentes ciudades.

Se producen cambios pragmáticos, es decir, en la acción, en la historia, porque ya no son romanos y numantinos enfrentados por la ciudad celtíbera, sino republicanos luchando contra nacionalistas y fascistas italianos por la defensa de Madrid. Sin embargo, no se constituyen cambios en las causas de la acción, porque en ambos textos se exalta la defensa de la libertad y la resistencia frente al opresor extranjero.

El hipertexto de Alberti supone una transposición, porque trata de contar la misma historia, pero de forma nueva, introduciendo una serie de transformaciones a nivel formal y temático. El aumento de lo simbólico en la versión de 1937 está motivado por la condición del público, y el mensaje que el emisor transmite supone su 
descodificación con mayor o menor dificultad. El autor se ve obligado a modificar el texto cervantino, eliminando todas las partes del mensaje que alteran la identificación de su actual referente - Madrid-y su situación en el espacio y en el tiempo. El cambio de coordenadas diegéticas se traduce en el texto a través de la introducción de calificativos como mussoliniano e italianos por romanos, un "signo icónico visual modificado", ' según Hermenegildo (1979: 150), porque Escipión aparece maquillado y vestido como Mussolini (viste un traje negro y lleva en el casco una calavera, el haz de flechas y el hacha dibujados en el pecho) y España luce un traje campesino, que conforman un lenguaje y un vestuario simbólicos. La identificación entre romanos y fascistas italianos, la introducción de símbolos obvios para el público republicano, las referencias explícitas a la guerra y el cambio en los finales de los actos alusivos a la contienda bélica dan cuenta de la actualización que realiza Alberti. Contribuyen a la eficacia de esta versión la presencia de soldados italianos entre las fuerzas nacionalistas enviadas desde Italia por Mussolini, como antes por Escipión, al igual que la identificación entre el general romano y el duce italiano.

Primariamente, se debe tener en cuenta el referente, porque la Numancia de 1937 es un texto adaptado a las circunstancias históricas, por lo tanto, "la función referencial del signo no puede ejercerse de manera unívoca" (Hermenegildo, 1979: 150). El referente primario son Numancia y los numantinos, pero Alberti lo utiliza en función de un nuevo referente, modificándolo: Madrid y los madrileños. Necesariamente, el autor debe alterar el hipotexto, para sugerir a través de una serie de signos (icónicos, deícticos, simbólicos) la identificación del nuevo referente (un verdadero correferente), el Madrid cercado (Hermenegildo, 1979). Reorganiza el texto cervantino en vistas del enfrentamiento bélico, pues introduce un correferente (Madrid, Franco, tropas nacionalistas) al referente utilizado por Cervantes (Numancia, Escipión, ejército romano) y emplea íconos, índices y símbolos derivados de la situación presente, que no tienen relación con la lucha numantina contra Roma.

El significante (Escipión) encarna dos personajes, tiene dos significados: el general romano que cercó Numancia y el general enemigo, Franco, que quiere conquistar Madrid. El signo icónico visual es percibido por el espectador y altera en él la hipotética identificación total con la Numancia histórica que podría haber elaborado: "El significante actor y el significado personaje no son unívocos" (Hermenegildo, 1979: 151).

A nivel semántico, es decir, alteraciones en el sentido o significado de la historia, se producen cambios en la función o efecto del texto en un nuevo contexto. En esta versión el autor modifica el final de la tragedia cervantina, porque en sus doce últimos versos se habla de la memoria que perdurará de la fama numantina, mientras en Alberti la tragedia concluye con un mensaje esperanzador: los últimos versos expresan confianza en un desenlace positivo de la contienda en favor de la República. La obra se cierra con las intervenciones de España y la Fama a diferencia del texto cervantino donde lo hacía solo la figura alegórica de la Fama. En la versión de 1937 las acotaciones señalan que "un gran sol se levanta, inundando la escena" y aparece España "en traje de campesina de hoy, llevando en una mano la hoz y en la otra una espiga" (110). El comienzo de los dieciséis últimos versos establece un paralelismo entre la tragedia cervantina y el momento presente: " $O$ Otra vez! Despertad, porque han llegado / los mismos invasores del pasado" (110). La Fama finaliza su parlamento ofreciéndole a España lo siguiente:

yo prometo grabarte en mi memoria, si el fascismo alemán e italiano halla en tus pies la tumba de su historia.

Esta página en blanco, España mía, tan solo espera el alba de ese día (111)
9. El ícono es un signo que establece con su referente una relación de analogía (representación). La semejanza puede ser además de visual, auditiva o cualquier otro signo imitativo (gustativo, olfativo, táctil) 
10. Dentro de las transformaciones semánticas (cambios en el sentido o significado de la historia), Pardo García, 2010 establece dos ejes: a) afirmativo (recuperación del hipotexto para mostrar su vigencia o completarlo); b) correctivo (recuperación del hipotexto para mostrar sus límites o sustituirlo).
España pronuncia los versos finales, declarando ante un grupo de romanos arrodillados ante ella, que vencerá al fascismo: "le cavaré un abismo y otro abismo / al sediento chacal alemán o italiano, / que España será al fin la tumba del fascismo" (111). Una luz brillante, simbolizando el sol que saldrá para España en un futuro cercano, marca el fin de la obra de Alberti.

A pesar de los cambios operados en el texto cervantino, la versión numantina de 1937 conserva el mensaje fundamental de su hipotexto: la defensa de la libertad aún a costa de la propia vida. Alberti pone de relieve la capacidad de actualización de la tragedia cervantina en el marco de la guerra civil española, razón por la que esta se resignifica, y es funcional en un nuevo contexto: es utilizada como un objeto de propaganda política a favor de la causa republicana o, en palabras de Hermenegildo (1993), como "un arma de combate" ( $\mathrm{s} / \mathrm{p}$ ) para animar a los madrileños, cercados por el ejército nacionalista, a resistir. Como afirmó el escritor Max Aub: "Nadie desdeciría las palabras de Escipión en boca de Mussolini, como nadie hallaría diferencias entre las palabras de los numantinos y los defensores de Madrid" (Jiménez León, 2000: 1185).

Alberti realiza una reescritura aproximada del drama cervantino desplazándolo a la guerra civil española, una transposición heterodiegética tanto en el espacio como en el tiempo. Se trata de una transculturización radical, pero que no altera sustancialmente el significado original del hipotexto, simplemente lo recupera y lo proyecta en un nuevo contexto, demostrando así su universalidad y vigencia para la exploración y exposición de los conflictos humanos provocados por la guerra y el imperialismo.

La Numancia de 1937 es aparentemente diferente de su predecesora por su desplazamiento transcultural, pero es una sobreescritura (Pardo García, 2010), porque no revisa ni subvierte el texto cervantino, sino que afirma y legitima su posición en el canon y su sistema de valores, pero llevando a cabo una actualización. Por lo tanto, es una escritura que homenajea y reivindica, no expone los límites de su antecesora (Pardo García, 2010), y es conservadora en relación con su hipotexto en términos ideológicos, porque conserva el ideal de la defensa de la libertad y la muerte en procura de ella. La Numancia de Alberti afirma la actualidad del texto precedente, su validez transcultural para examinar otros conflictos en otras coordenadas culturales y, por tanto, el universalismo del clásico. En consecuencia, se efectúa una transformación semántica afirmativa (Pardo García, 2010). ${ }^{10}$

Si bien este estudio se centra en la Numancia de 1937, cabe mencionar, a grandes rasgos, los motivos que llevaron a Alberti a escribir una nueva versión de la tragedia cervantina. En 1943, ya exiliado y acabado el conflicto bélico en su país, Alberti escribe durante su estancia en Buenos Aires la nueva versión de la Numancia para ser representada por su compatriota, Margarita Xirgu, en Uruguay, país fuertemente democrático, salido recientemente de un período dictatorial, hogar de miles de inmigrantes españoles y donde la mayor parte del espectro político había expresado empatía con la causa republicana. Al respecto, Alberti afirmó en el prólogo de su obra: "Obra predestinada Numancia, tenía que aparecer en América, en el Uruguay" (Alberti, 1943: 13). Esta nueva versión está determinada por el exilio del escritor, la distancia emocional, la derrota de la causa y un único triunfo posible proveniente de una derrota digna y valerosa como la de los numantinos. En ella, el escritor recupera el simbolismo numantino en función de los derrotados republicanos en el exilio, para refundar una identidad histórica. Pero también la resignificación del texto cervantino en un nuevo panorama político-mundial da cuenta de una voluntad universalista sobre la defensa de la libertad, que sobrepasa el modelo numantino - español planteado por el autor en su anterior versión, y lo hace extensivo a todos los pueblos que defienden su libertad. Se trata de una versión que está libre de urgencias propagandísticas y no expresa una ideología coincidente con la oficial, pues supone "un emisor más 
reposado, no identificado con el receptor, y un receptor menos implicado emocionalmente en la acción referencial" (Hermenegildo, 1979:159). El final de la tragedia posee unos versos nuevos en los que España recobra el aire profético, que había perdido en la versión de 1937. Finaliza con la Fama augurando la victoria futura de los españoles y España cierra la obra con un solo verso: "Y aquí se cierre el libro de su historia" (116), mientras se hace el oscuro en el escenario. El mensaje es claro: el franquismo se ha impuesto en España y la oscuridad durará casi cuatro décadas.

\section{Conclusión}

Los motivos que impulsan a un escritor a realizar una reescritura de un texto legado por la tradición literaria son de diversa índole. En el caso de la reescritura de El cerco de Numancia, de Miguel de Cervantes, que realiza Rafael Alberti en 1937, las causas pueden atribuirse a razones de tipo literario $y / o$ consideraciones relativas al contexto social y político de su aparición/recepción, que irradian algunas obras consideradas canónicas, definidas como "aquellas con la facultad de sobrevivir al paso del tiempo, dispuestas siempre a ser recuperadas de la memoria colectiva para transmitir nuevos mensajes a individuos diferentes" (Solá Perera, 2005: 4).

En el contexto de la guerra civil española los intelectuales republicanos recurrieron a la tradición literaria más arraigada en la historia de su país y la pusieron al servicio de la causa política que defendían, como forma de participar literariamente en el conflicto bélico que atravesaba su nación.

Alberti se apropia de la tragedia cervantina y realiza una adaptación de circunstancias, poniéndola en relación con la guerra civil desde una visión favorable a la República española y opuesta a los nuevos invasores italianos. La versión albertiana sirve como instrumento de propaganda para la construcción de un sentimiento de patriotismo encarnado en el mito numantino, estableciendo así un paralelismo entre la histórica defensa de Numancia y la heroica defensa de Madrid por los republicanos.

La Numancia de 1937 es una versión bastante libre de la tragedia cervantina, pues Alberti suprime versos y agrega otros, elimina mayoritariamente las alusiones a la mitología grecolatina, actualiza el léxico, agrega un correferente a los utilizados por Cervantes, introduce un prólogo que antecede el comienzo de la obra y modifica su final con el cometido de lograr una comunicación más ágil y directa con el público republicano, y así sugerir la semejanza histórica de aquel momento con el actual.

El escritor no solo adapta el texto de Cervantes, sino que lo moderniza, porque reemplaza la casi totalidad de los elementos que constituyen la comunicación dramática de su predecesor. De esta manera, utiliza el intertexto cervantino para hacerlo dialogar desde una perspectiva diferente, la suya propia y la del público de 1937. Esta interposición de la obra cervantina entre el escritor y la guerra civil ha producido una obra nueva y distinta por su contenido y alcance, pero se mantiene fiel respecto al mensaje de su hipotexto: rescata y conserva en su adaptación su sentido de apología de resistencia ante el invasor, manifestando la atemporalidad del mito numantino y la identificación del heroísmo numantino-español, así como el sentimiento de amor por la tierra/patria y el ideal de la muerte en su defensa. 


\section{Q Bibliografía}

» Alberti, R. (1937). Numancia. Madrid: El Signo.

»Albistur, J. (1968). El teatro de Cervantes. Montevideo: Fundación de Cultura Universitaria.

»Baras Escolá, A. (2014). "Las dos Numancias de Rafael Alberti”. eHumanista/ Cervantes 3, 243-273.

»Cervantes, M. de (2014). Tragedia de Numancia. Edición de A. Madroñal Durán. Alicante: Biblioteca Virtual Miguel de Cervantes. En: http://www.cervantesvirtual.com/nd/ark:/59851/bmc864co; obtenido el 13/6/2020.

"Cortadella, J. (2009). "La Numancia de Cervantes: paradojas de la heroica resistencia ante Roma en la España Imperial”. En: Actas del XI Coloquio Internacional de la asociación de Cervantistas. Seúl, 17-20 de noviembre de 2004, 557-570.

" Genette, G. (1989). Palimpsestos. La literatura en segundo grado. Madrid: Taurus.

"Hermenegildo, A. (1979). "El proceso creador de la Numancia de Alberti”. Imprévue, 1-2, 147-162.

"Hermenegildo, A. (1993). "El parapeto intertextual albertiano y el compromiso de la guerra civil”. Anthropos, 148, 61-64.

» Jiménez León, M. (2000). “Rafael Alberti y La Numancia de Cervantes”. En: Bernat Vistarini, A. (ed.). Volver a Cervantes. Actas del IV Congreso Internacional de la Asociación de Cervantistas. Islas Baleares: Universidad de las Islas Baleares, 2001, 1187-1200.

»Pardo García, P. (2010). "Teoría y práctica de la reescritura filmoliteraria (A propósito de las reescrituras de The turn of the screw)". En: Pérez Bowie, J. A. (coord.). Reescrituras filmicas: nuevos territorios de la adaptación. Universidad de Salamanca, Ediciones Universidad de Salamanca, 45-102.

»Puchau de Leccea, M. (2014). “Numancia. Miguel de Cervantes, 1580 - Rafael Alberti, 1937”. En: Greco, B. y L. Pache Carballo (coord.). Variaciones de lo metarreal en la España de los siglos XX y XXI. Madrid: Biblioteca Nueva, 321-330.

» Ropero, A. (2010). Mártires y perseguidos. Historia general de las persecuciones (siglos I al X). Barcelona: Editorial CLIE.

»Solá Perera, D. (2005). En busca de un discurso identitario y canónico: la reescritura de Rhys y Coetzee en Wide Sargasso Sea y Foe, Tesis doctoral, Universitat Pompeu Fabra.

»Vivar, F. (2000). "El ideal pro patria mori en La Numancia de Cervantes". Cervantes: Bulletin of the Cervantes Society of America, 20.2, 7-30. 